\title{
Who cares? A defence of judicial review
}

\author{
Susanne Baer
}

Maccabaean Lecture in Jurisprudence, read on 25 November 2019

Abstract: For a long time, politicians and scholars and even judges have criticised national and international courts with the competence of judicial review of legislative and executive powers. The defence usually relies on more or less abstract notions of the rule of law. This article, however, argues that at the heart of the matter are people, as protected by fundamental rights. Critical approaches to the law and studies in comparative constitutionalism allow us to understand why judicial review matters, namely: to whom. From that point of view, judicial review is not just a debatable idea, but it is about, specifically, children and women, non-patriarchal men and social and cultural minorities, poor people and others who are excluded. These are people in need of courts. For people, the rule of law is not just another concept of how things may be run, but is a protective device against arbitrariness, or outright hostility, of political majorities. Way beyond a reference to Germany's history, judicial review is a 'never again' to law as an empty promise.

Note on the author: Susanne Baer, an International Fellow of the British Academy, serves as a Justice in the First Senate of the German Federal Constitutional Court and holds a position as Professor of Public Law and Gender Studies at Humboldt University of Berlin as well as the Global Faculty at Michigan Law School, and has been visiting faculty at CEU Budapest for ten years. She has been awarded honorary degrees from Michigan Law School, USA, Hasselt University, Belgium, and University of Lucerne, Switzerland. She has been an activist against domestic violence, the director of an advisory centre on gender mainstreaming in German federal policies, and a key advisor on equality efforts in universities. Her research focuses on the protection of fundamental human rights and comparative constitutionalism, critical legal theories and legal gender studies, and sociolegal and cultural dimensions of the law.

Keywords: Fundamental rights, human rights, judicial review, constitutionalism, democracy, rule of law, minorities, German unification, 'Volk' / the people.

(C) The author(s) 2020. This is an open access article licensed under a

Creative Commons Attribution-NonCommercial-NoDerivs 4.0 Unported License 
For a long time, there has been criticism of national and international courts with the competence of judicial review of legislative and executive powers, in politics as well as in scholarship and legal practice. Usually, a defence relies on a more or less abstract notion of the rule of law. However, one may also wonder about the heart of the matter. Critical approaches to the law as well as studies in comparative constitutionalism help us to understand why judicial review matters, namely: to whom. From that point of view, judicial review is an indispensable element of the protection of fundamental human rights. It is about children and women, non-patriarchal men and social and cultural minorities, poor people and other excluded people, because they are in particular need of courts. Thus, the rule of law is not just another concept of how things might be run, but must be understood as a protective device for those otherwise lost to the arbitrariness, or outright hostility, of political majorities. In other words, it is a 'never again' to law as an empty promise.

We live in turbulent times. The day one accepts the honour of an invitation to give the Maccabaean Lecture in 2019 seems far away from a moment shortly before national elections and right after a significant ruling from the UK Supreme Court on prorogation of parliament. One wonders, like eminent scholar Brian Simpson did before me (Simpson 2004), whether it was naïve or simply stupid to accept the honour of this invitation. Yet there is, in 2019, an urgent necessity to make up your mind, specifically, on judicial review. Somewhat different from many rule-of-law defences, I call on you to care - for people in pain, for those who suffer, for those eventually left behind, if there is no judicial review.

In light of history, then, this lecture could also have been named: 'Never again an empty promise'. Historically, the means to deliver the promise of constitutional democracy is judicial review. Courts with that power stand for, and protect, a structure of governance that does not allow any majority, however large its win in elections, to trump anyone. The promise is: No one shall ever again trample over any individual, because each and every human being deserves the same respect.

Constitutionally speaking, this is the grand consensus after 1945, the post-WWII agreement, the post-colonial mindset, the post-authoritarian rule. It says that dignity, liberty, and equality shall not simply be promises on paper, or an elitist privilege for a few. And backed up by courts, they are designed as promises to be kept. The message is thus also: A text-or a mix of texts and rulings and conventions - is not enough to safeguard democracy and fundamental human rights. In addition, you need judicial review.

The post-WWII, post-colonial, post-authoritarian agreement resulted in varieties of constitutionalism, but it defined a baseline for all. But there is much less consensus about this baseline today than one might have hoped for after 1989, after the fall of the Cold War wall. In the 21st century, the grand consensus is under attack, and such 
attacks specifically target courts with the power of judicial review. The first part of this lecture sketches some of these developments, with important anniversaries to celebrate and many reasons to worry in 2019. This shows why it is high time to remind ourselves of, and to refine our concepts of, in order to defend - and eventually update, yet not destroy - what constitutionalism is really about: a democratic society with a guarantee of fundamental human rights, that is thus based on a substantive rule of law. The second part will address some prominent lines of critique levelled against judicial review, to eventually rebut them. Last but not least, the final part returns to the foundational promise of constitutionalism: democracy, the rule of law, and fundamental rights beyond an empty promise (from a German point of view, see Grimm (2016)). If we were to live in a world without it, some people would suffer and, therefore, we should care.

\section{9}

The year 2019 is the right year to reflect on judicial review. It is a year of great celebrations, constitutionally speaking, and a worrying year as well. There are several important anniversaries in 2019, and thus reason to celebrate, yet at the very same time, the basic consensus is under attack. And this is not just another trend in politics. The attacks are particularly worrying because they are out to destroy the law in the name of the law, and thus undo the safety belt for democracy and fundamental rights. This is not a paradox, but a simultaneous and interrelated occurrence: Constitutionalism is alive and very well, and it is severely threatened.

Certainly, there are tensions within constitutionalism that are coming to the fore. In multilevel and pluralist legal orders, formerly national systems face complicated problems we need to address - as Lord Thomas, Lord Neuberger, Lord Hope, and Sir Konrad Schiemann did in the European Parliament, in 2017. But they did so to defend the rule of law, not to undermine it. We need to, as Neil Walker (2019) puts it, revisit constitutionalism's 'underlying anxieties', but we must resist the polarisation between yes and no to — or in current UK parlance: stay or leave — specifically, judicial review.

\section{Success}

So let us celebrate. In the 21st century, there is more of what Amartya Sen calls a 'democratic commitment' in the world (Sen 1999), more constitutional texts with fundamental rights, democracy, and orchestrated powers not to violate them, and, last but not least, more judicial bodies than ever to exercise judicial review (e.g., Schor 2008, Oberleitner 2018). It is, again, the post-WWII consensus, as well as a postcolonial 
contrat, a post-dictatorship commitment, a post-Cold-War anti-authoritarian agreement. Since 1945, and in a big wave since 1989, constitutionalism implemented via courts with the power of judicial review has become a key means to replace fascist, colonial, military, or otherwise dictatorial rule, by democratic governance. 'Never again' should there be, in an analogy to the challenge of 'fake news' as the reporting dress of invented stories, what one may call 'fake law', the legal dress of injustice. After 1945 etc., 'never again' should there be what Hannah Arendt described as the 'banality of evil', ${ }^{1}$ an efficiently rule-based yet utterly unjust regime of terror. Therefore, and across continents, people fought for, designed, and eventually implemented systems of governance to deliver the great promise of a more inclusive, and thus more diverse, 'we the people'. And this included judicial review.

In the British Academy, there is another option to describe these efforts and developments: New constitutionalism is also an update of Clause 29 of Magna Carta from 1215. There, the promise was that equal 'liberties' were held by the 'free man'. Now, the promise is to ensure dignity, liberty, and equality to any human being; whether they identify as man, woman, or other, wherever they come from and whatever they possess, they are all subject to the same 'law of the land', the written or unwritten constitution. Yet to acquire real meaning, this update from 1215 must today include independent institutions bound by law and with the power of judicial review. Such courts adjudicate conflicts over the basic rules of democracy, schemes of governance, both domestic and in international relations, and protect the fundamental needs of people. Look at the 'new' South Africa after Apartheid, at Brazil and Colombia, at South Korea, at Taiwan, or at the more recent jurisprudence of the French Conseil Constitutionnel - these courts play a key role in their respective contexts, particularly when they protect people.

The year of 2019 offers even more for a constitutionalist to celebrate. In the shared regional space in which we live, there is the sixtieth anniversary of the European Court of Human Rights (ECHR) in Strasbourg, the shining light in human rights protection, and a model for many. Very different countries send their judges to one bench, where they meet with their diverse languages, experience, legal traditions, methodological approaches, and ways to frame a case, yet have found, again and again, a consensus on human rights (Nussberger 2019). In another region, we can celebrate the fortieth anniversary of the Inter-American Court of Human Rights, designed to enforce the American Convention of Human Rights, which it did, to protect people beyond the mainstream, often boldly (Buergenthal 2004, Contesse 2017). Also, the African Court on Human and Peoples' Rights issued its first ruling ten years

${ }^{1}$ Arendt (1963). Arendt was fascinated by US constitutionalism, albeit with a particular perspective on judicial review (see Baer 2019a). 
ago, in 2009 (Daly \& Wiebusch 2018, Jalloh et al. 2019) And in Asia, there is no court-enforced human rights system yet, but a small institutional step was taken when the ASEAN Intergovernmental Commission on Human Rights was inaugurated.

In addition, there are many national developments to praise. In Britain, many, but not all, women gained access to practising law, by a 'removal' act in 1919. Thus, the German story is but one among many. However, it may offer some insight into what birthday parties look like today.

In Germany, the first democratic 'Weimar' constitution was agreed upon, signed, and published 100 years ago, which also indicates 100 years of women's right to vote. This did not give the vote to all women, but many more were recognised as having a say in res publica than before. However, the Weimar constitution (Dreier \& Waldhoff 2018, Gusy 1997) featured principles, but not enforceable fundamental rights, and it was a constitution unable to defend itself when fascists took over.

Much more prominently, then, in 2019, Germans celebrated seventy years of the Basic Law, the post-WWII text to form a human-rights-based, democratic, and defensive - or as Karl Loewenstein called it 'a militant'2 — constitutional democracy, with a specialised constitutional court. And although there was a broad commitment and an agreed-upon text, this German Federal Constitutional Court (FCC) had to make sure, in one ruling after another, that the promises were kept, and it had to establish itself as a serious actor in the scheme of checks and balances, a 'constitutional organ' next to government, parliament, the second chamber, and the president of the country. ${ }^{3}$ Then German Chancellor Adenauer was, famously, 'not amused' when the Court stopped his plan to have government television; the Court eventually developed a jurisprudence of public independent broadcasting with a mandate to offer more than one view (BVerfGE ${ }^{4}$ 12, 205 - 1961, Deutschland Fernsehen), and it later protected media against police intrusion (BVerfGE 20, 162 - 1966, Spiegel). There as in many other controversies over public policy with the government as well as with parliament, the Court did protect the dignity of the poor, the liberty of outsiders, equality for the other, and democracy for all. Not everything was perfect - there was always a degree of uncertainty (Vermeulen 2006), there was no progress without hurdles on the way, and there was always room for improvement, with all the challenges of assessing constitutional practice (Ginsburg \& Huq 2016) — but there was lots to celebrate.

\footnotetext{
${ }^{2}$ For further references, see Dorsen et al. (2016), on constitutional guarantees of democracy.

${ }^{3}$ On the history of the court, see Lamprecht (2011), Lembcke (2007), and Stolleis (2011); for a US perspective, see Collings (2015); on doctrinal developments see Kommers \& Miller (2012).

${ }^{4}$ German Federal Constitutional Court (FCC) decisions are published by the Court, in 'BVerfGE'. On the Court's website, major decisions are also published in English, and are searchable with their original Court edition citation.
} 


\section{Worries}

However, this is not the whole picture. In 2019, courts, and specifically human rights courts and courts with a constitutional mandate of judicial review, are under aggressive attack or have already been destroyed. This is not the first time there has been a feeling of 'crisis', but basic rights are certainly under pressure today. ${ }^{5}$ This is not being done in a revolutionary turn, but in the name of law, in subverting its very meaning. Some courts have thus been taken over, keeping just the façade, and such courts still function formally, but in substance they do not provide a check on political power. In fact, they do not protect democracy nor do they care for people who are kept out, or left behind. Again, there are varieties of constitutionalism, as there are versions of populism and different developments in context. But to name a few, Hungary and Poland, Russia, Bulgaria, Romania, as well as Turkey, have changed rather dramatically in recent years. In many countries, judicial review has either been discarded or is in bad shape and may not deserve the label any more. In the US, there are similar worries when judges are attacked (as already described by H. Baer (2011)), yet courts are staffed to become instruments to 'make America great again', ${ }^{6}$ and so a different place, and thus are heavily politicised, to serve the few rather than function as 'a never again' for the many.

Again, contexts differ and have to be taken into account. But, interestingly, the cookbook for many such destructive developments is an autocrat's handbook. There are more or less obvious moves of what Javier Corrales (2015, see also Neves 1997) and Kim Scheppele (2018) named 'autocratic legalists' who employ a specific set of arguments and activities to strategically undo constitutionalism itself. They undo democracy and trump fundamental rights, but claim to act in the name of democracy and in the name of the rule of law. This makes these recent developments particularly hard to fight, and particularly dangerous. Also note that the prime targets of such autocratic politics are the media, the academy, and the arts, to silence critique and dissent. Yet the courts are targets in order to destroy the institution with a mandate to stop them, and eventually to protect the media, the academy, and the arts. Courts are institutions to limit and exercise control. In such a global context, the slogan of the

\footnotetext{
${ }^{5}$ In the 1970s, the 'crisis' of the rule of law was a lack of implementation and 'overregulation', as well as the increase in preventive police powers in a response to terrorism (e.g., Benda 1972). Also, the failed attempt to agree on a constitution for the EU has been discussed as a 'crisis' (e.g., Kadelbach 2018). In 2015, German conservative constitutional lawyers called the challenge of migration a 'constitutional crisis', inspired by an expert opinion from former FCC Justice Di Fabio, commissioned by the government of Bavaria; see a critical response from Preuß (2017). On fundamental rights and populism see Baer (2019b).

${ }^{6}$ Donald Trump's slogan in his 2016 presidential election campaign.
} 
UK campaign to leave 'Europe' in order to 'take back control'7 has highly problematic echoes.

Populist rallying cries are, then, that 'we the people' or 'the people's true will' or 'voice' must be reinstated to overcome 'chaos' or 'disorder', attributed to migration, social and cultural diversity, variations in beliefs, families, and intimate lives, or even clothing. Populists then demand a 'return to the rule of law', but what they mean when this is looked at in detail is law as a means of their power to crush those they dislike, unhindered by, specifically, judicial review. In this vein, politicians promote an 'illiberal democracy' or 'our version' of the rule of law. But they propose not just another version of a participatory political regime, but undermine the grand consensus post-1945. Therefore, there is a need to defend such foundational terms against their enemies; what autocratic legalists want does not deserve these labels. ${ }^{8}$ Whoever proposes government not bound by law, not bound by the rules of democracy and fundamental human rights, does indeed practise or support what Tomasz Tadeusz Koncewicz calls a 'a politics of resentment', ${ }^{9}$ specifically in nationalist racism, patriarchal sexism, corrupt privilege, and unhindered power. This is not constitutionalism but its destruction. It is autocratic legalism indeed.

\section{From Leipzig to Berlin}

The strategy of manipulating foundational terms and commitments to democracy and fundamental rights, to prepare for the unfriendly takeover of institutions and their power, and to employ all means of communication and political mobilisation that were once the domain of civil society movements is highly dangerous. Also, it is not an isolated problem of one country or region ${ }^{10}$ but happens, with variations, all over. In 2019, there is another anniversary with which to illustrate the risk: the thirtieth

\footnotetext{
7 'voteleavetakebackcontrol.org' (last visited 8 December 2019) is a website with a warning that, if the UK stays in the EU, immigration will continue to be 'out of control', explicitly rejecting people from EU 'poorer' member states, and a warning that 'the European Court will still be in charge of our laws', which 'already overrules us on everything', opposed to, when the UK leaves the EU, 'we can make our own laws'.

${ }^{8}$ Although I agree with much of the analysis by David Landau (2013), the label 'abusive constitutionalism' runs the risk of establishing this as one version of constitutionalism, rather than the name it deserves of 'denial of constitutionalism'.

${ }^{9}$ Koncewicz (2019) regularly publishes on 'constitutional backsliding', specifically in Poland. See his contributions at: https://verfassungsblog.de/author/tomasz-tadeusz-koncewicz/

${ }^{10} \mathrm{Krastev}$ and Holmes (2019) understand the developments in Eastern Europe as a result of the overly ambitious installation of constitutionalism without enough of a base. At the time, some advisors had suggested a first focus on the economy, and later on democracy, civil rights, and the rule of law. But who would then have been left behind?
} 
anniversary of the 'velvet' revolution, which in Germany is known as the 'peaceful', the 'friedliche Revolution'. It has been optimistically called the end of the Cold War, and some celebrated it as the victory of capitalism; after all, it gave rise to a new wave of constitutionalism. But things changed, eventually.

In 1989, citizens in the then GDR peacefully pressured their government, on the since-then famous Monday marches, to hold free elections and ensure human rights, namely personal liberty, freedom of the press, and an end to surveillance. Famously, their rally call was: 'Wir sind das Volk', 'we are the people' — not you, a government that does not have the right to speak in our name. These citizens constructed a pouvoir constituant, the people as the subject to form a democratic state. A wonderful event to celebrate today.

But the slogan changed. Already in 1989, 'We are the people' became 'Wir sind ein Volk', 'we are one people', in one unified nation. Now the focus was to 'tear down this wall', echoing US President Reagan's symbolic appeal to then Russian President Gorbatchev. And when people chanted 'we are one people', some others were a bit worried that nationalist chauvinism could crawl back.

Then, in 2014, populist nationalist autocrats indeed took over. As part of an international movement, racist and anti-Semitic, neofascist and anti-democratic nationalist populists organised as Pegida - Patriotische Europäer gegen die Islamisierung des Abendlandes ('Patriotic Europeans against the Islamization of the Western World') (Bude 2019, Jörke \& Nachtwey 2017, Müller \& Precht 2019). Their platform eventually informed the party now elected into most German parliaments, somewhat appealingly named 'Alternative for Germany', now 'AfD' (Wildt 2017).

Still, many insist that, as the protesters' slogan said, 'in fact you are not the people - no AfD', and 'Nö, wir sind das Volk', 'No, it is we who are the people'. But the insistence on 'we are the people' was louder, more aggressive, and scarily successful. The emphatically proud 'Wir sind das Volk' is then loaded with nationalist racialised and gendered meaning (Dietze 2017, 2018, Hark \& Villa 2017). It quickly becomes the 'true will of the people', a pretty democratic tune. But, in fact, it calls for a political regime that fails to meet the great commitment post-1945. This 'we' positions an ethnically and religiously exclusive majority against all others, namely 'foreigners'. It does not target all of 'them', but those stigmatised as visibly the wrong ones. In addition, this 'Volk' rallies against 'elites' and a 'lying press', and is opposed to 'system parties', a phrase from Nazi propaganda in the 1930s to, again, in fact destroy democracy. In 2019 German state elections, the AfD put up placards that said 'now and then: we are the people' ('Damals wie heute: Wir sind das Volk'). The reference was 1989, but in fact, the ideology is 1933 et seq. The AfD added 'let's finish the peaceful revolution' ('Beende die Wende!'), and cited eminent social democrat Willy Brandt's call to 'dare more democracy' ('Mehr Demokratie wagen') from 1969, 
another anniversary. But, in fact, the current nationalist populist version of politics does not deserve the name, because it is 'illiberal'.

Yet these political movements also challenge our understanding of the rule of law. In German elections, the AfD posted 'Geltendes Recht durchsetzen' ('implement the law'), and framed itself as the true defender of 'our' rights. But, in fact, this political movement is out to destroy what law promises. The minute a court upholds the right of a foreigner not to be deported to a country that practises torture, such autocratic legalists question the legitimacy of courts and the qualification of judges, who should be 'more in line with the people'. Similarly, when a court deepens the commitment to European integration and global cooperation, not least an element of the German Constitution from the preamble to Article $23 \mathrm{BL}$, such populists are not at all interested in the law but tend to protest about what courts do. Generally, rulings that protect refugees, or intersexuals, or homosexual couples, or mothers beyond the nuclear family, or that protect democracy itself, tend to be called 'exaggerated', 'activism', risking a 'loss of values'. Yet to advance in parliament and other positions of power, and to win what Germans sometimes call the 'Lufthoheit über den Stammtischen' ('air control over the regulars' table'), autocrats tend to use all available means.

Now what happens here? What does it mean, in Germany, in the UK, wherever we see such changes in meaning?

Autocrats send anti-democratic politicians into democratic institutions: for example, anti-Europeans to the European Parliament. Autocratic legalists 'reform' the courts, and destroy their independence. They are backed up by radical groups in the streets, driven by hatred and prone to violence, that claim rights to association and freedom of speech and the press. In academic contexts, they complain of 'political correctness' and imply it is censorship to silence others, and make claims about academic freedom to eventually do away with it (on the US, see U. Baer (2019)). Online, they claim the right to free speech to silence others and to spread hate. It is the handbook of the autocrat that advises the use of constitutional rights in a vibrant democracy to in fact destroy it. Former US Secretary of State Madeleine Albright (2018), herself from a family that lived through and who herself later dealt with authoritarian regimes, describes the tactics as 'plucking the chicken' to eventually eat it. Small and seemingly technical reforms amount to unfriendly takeover. And, often, the defence points to other countries that do the same, picking from varieties of comparative constitutionalism, yet entirely decontextualised, in order to destroy it. ${ }^{11}$

\footnotetext{
${ }^{11}$ Such a strategy should not be called cherry picking, as the risk in comparative studies is to only look for proof of one's own convictions. Instead, the strategy used by autocrats should be called 'poison dripping', because they use elements that are not destructive in their context, yet have a poisonous effect when mixed with more such ingredients in another setting.
} 
This is why 2019 is a year to celebrate, but also time to worry that our very basic consensus is eroding.

\section{9 in the UK}

Obviously, this is not a fairy tale from across the Channel. The tactics and success of autocratic legalists worry many people in many places. In London and for the UK, the year 2019 also seems not to be just another year.

Here, I assume that constitutionalists will commemorate the Bill of Rights: it dates from 1689. Certainly, there must be a party for the tenth anniversary of the UK Supreme Court. Similar to so many courts around the world, this court had to pave some of the way itself, yet it even did so as more than a national actor, also beyond a Commonwealth actor. Swiftly, the UK Supreme Court established itself as a strong and truly influential constitutional court on the global map, in that vital mix of courage and care that such courts need. In addition, the UK Supreme Court is pretty avant-garde. It resides in a neo-Gothic building in Parliament Square, but is stacked with screens and communication devices and the option to simply sit in, allowing people to see how law is done. Not least, since the public - and us as well, human beings after all - pick up pictures first, there is also the large sparkling spider on black fabric, which the court's President Lady Hale wore when she read, together with VicePresident Lord Reed, the unanimous ruling on prorogation in 2019. Thus, this must be quite a party.

Yet again, there is also the other side. There is the process - not an act nor a fact — of Brexit. It exposes the complicated and utterly ambivalent nature of referenda as a democratic means. Also, this process exemplifies the complexity of multilevel governance today, including the fact that leaving one international unit does not result in leaving the legal web of international relations. To leave the EU does not automatically result in leaving trade agreements with the EU or its member states, nor does it result in 'leaving' the European Convention of Human Rights, specifically when this has been transposed into national law as a Human Rights Act in 1998. But in addition, 2019 is the British year of what was labelled a constitutional crisis of dimensions not seen since the 17th century. And this did not necessarily refer to Brexit, which indeed poses constitutional questions for the UK, for the EU, and for EU member states, and for other states and international organisations the UK dealt with via Europe. Instead, the diagnosis of a constitutional crisis refers to the Supreme Court rulings, and is thus levelled at an activity that is in fact meant to keep a crisis at bay. At the least, this reminds me of the typical populist move of autocratic legalists who claim the law to break it.

As such, 2019 did not only offer an intensive seminar in British politics for the world to watch. Your fellow Europeans, and Germans-known to be in love with 
Britain in a wholehearted embrace of the Queen, The Beatles and Adele, Monty Python and Abbey Road, as well as Miss Marple, and Harry Potter and Hermione, to name but a few ${ }^{12}$ - did watch this intently. But in our admiration for the land of Magna Carta, with democratic traditions so much longer than our own, there was also a shock. How can this be: individual judges exposed in British tabloids as 'enemies of the people', and, even more shockingly, those with a voice and even those with a mandate to take care of the rule of law not swiftly explaining what is so utterly wrong and unacceptable in that exposure? How come there is, in Britain, a 'Judicial Power Project' (https://judicialpowerproject.org.uk/, run by a political think tank, Policy Exchange), that sets out to understand the 'undue rise of judicial power', define the 'proper scope of the judicial power within the constitution', and stop 'judicial overreach', and is able to enlist scholars to further its cause? How can there be a Leave campaign that in no insignificant part features attacks on judicial review specifically directed at international and human rights courts, in Luxembourg and Strasbourg, again with some prominent jurists in its sights?

In 2019, such worries culminated in some reactions to the judgement of the UK Supreme Court on prorogation. The UK Attorney General, Geoffrey Cox QC, is on record as having warned members of parliament that 'there may very well need to be parliamentary scrutiny of judicial appointments in some manner'. ${ }^{13}$ Is this a suggestion, or a threat of what is known around the globe as court-packing and unpacking? Does it imply that today's judiciary is not qualified? Or is there an expectation that parliament should put people on the bench who deliver what politics expect, and thus not practise independent judicial review? In Germany, a member of the state government made similar remarks when administrative courts stopped the deportation of someone to a country that practises torture. In Hungary and in Poland, such a calling into question of court authority paved the way to undoing their independence. So what does it mean to you? Watching from a distance and celebrating the grand consensus of 'Never again', it is at least irritating when media reports that a Supreme Court ruling has been called a 'constitutional coup' by prominent politicians, or when the Prime Minister 'strongly disagrees' with a ruling and 'will not be deterred from getting on and delivering on the will of the people'. What does this mean?

We have anniversaries to celebrate, but also reasons to worry.

\footnotetext{
${ }^{12}$ The German national 'House of History' curated an exhibition on the German view of Britain in 2019, with a catalogue Very British. Ein deutscher Blick.

${ }^{13}$ https://hansard.parliament.uk/Commons/2019-09-25/debates/F3541B98-D4E9-487F-BE17-

D51C6EF870F2/LegalAdviceProrogation
} 


\section{THE CRITICS}

Certainly, autocratic legalists vary in strategy, in wording, and in tone. Different versions of populism have, as Nicola Lacey explains, different degrees of systemic or contingent proximity to the rule of law (Lacey 2019, see also Baer 2019b, Bugaric 2019, Dixon \& Landau 2019) Contexts matter, as do details. In addition, the populist attacks on courts are often simply unbearable: wrong, without respect or knowledge, not interested in doing better, but purely destructive. However, there are also lines of criticism that deserve our attention. Many are well known, others new, and all risk being employed by autocrats. Therefore, it is necessary to prepare sound arguments in defence of judicial review, both to respond to the critics and to prevent capture by the wrong side. Unprepared, one easily falls into the traps set by strategy populists to enlist well-established scholarship and plausible skepticism. So before I turn to the substantive reason of why we should care, I will address some prominent lines of critique of judicial review.

\section{Genealogies and politics}

In many Anglo-Saxon contexts, criticism of judicial review refers back to Abraham Lincoln's First Inaugural Address, in which he warned of 'despotism in some form', a line later picked up by the influential political theorist Jeremy Waldron (2006). Such critique of judicial review became part of the canon, in a political context that does not allow for much of a dialogue between the court and other branches, very different from highly 'dialogic' contexts with the power of parliament to reverse any judgement politicians dislike.

In the late 20st and early 21 st centuries, this criticism spread, across common law and civil law systems. Now, it is a reaction to the success of court-empowered 'new constitutionalism' (Shapiro \& Stone 1994) that has spanned the globe, which so many celebrated in 2019. Where courts are mandated to control all branches of government (including parliament), academics, with a reference to early comparative studies in France (Lambert 1921) warn of a 'gouvernement de juges' (Stone Sweet 2000), 'government by judges', a 'juristocracy' (Hirschl 2009). Often, this inspires political fights against 'foreign judges', as in the failed referendum in Switzerland on leaving even regional human rights systems, ${ }^{14}$ and it informs much skepticism regarding the EU, as in the British Leave campaign as well as in proposals to also leave the larger Europe, and

\footnotetext{
${ }^{14}$ Right-wing politician Christoph Blocher had already called for an end to commitments to international human rights in 2007, in his Bundesfeierrede (Federal speech) ('Gegen fremde Richter!'), and the SVP (Swiss People's Party) then launched the referendum 'Schweizer Recht statt fremde Richter' in 2013, in which 66\% voted no in 2018.
} 
thus the European Court of Human Rights, or other multilateral commitments such as those to human rights treaties and enforcement mechanisms in the UN. To name but one example, when French politician Marie LePen rallies against the 'gouvernement de juges', academic headings become the repertoire of autocrat populists (Baer 2019b).

But what do the critics dislike about judicial review?

\section{Simple disagreement}

Sometimes, critics simply disagree with a particular ruling, albeit in grand words. This is limited to the controversy at hand, and to doctrinal questions of legal interpretation in that given case. But it is my impression that such criticism primarily targets decisions on fundamental rights, and thus decisions to protect individuals or minorities, the 'other' who does not belong, while court rulings on what are considered purely economical questions, namely to ease market transactions, are spared.

\section{Greedy actors?}

Other critics claim that courts are 'greedy', just like any other political actor (Sturgess $\&$ Chubb 1988). Conceptually, this seems a bit flawed. The greed assumption resembles the construction of the rational subject in economic theories: the man who always wanted more. But that rationality was soon exposed to be a rather limited and boringly foreseeable trait, helpful for designing research, but inadequate for capturing reality. Feminist and otherwise critical analysis demonstrated convincingly that this 'economic man' is a problematically reduced persona of classical patriarchal masculinity, with an utter lack of trust or care (e.g., Ferber \& Nelson 2009). To understand economic interaction, we need to do better, as in analyses of judicial review.

The greed assumption also risks ignoring the nature of judicial review. Notably, courts are entirely responsive institutions: the legislature charges them with deciding cases if they are brought according to the rules. Neither jurisdiction nor access to courts is defined by judges, but determined by law, and thus by politics. As a judge, one may wish to get a particular case, because that question of justice might have been a calling that inspired one's engagement with the law. But in fact, it is not in our hands, and many such dreams do not come true.

In addition, the greed assumption may overlook the structural fact that courts do not have much to lean on when they intervene. Courts with the power of judicial review of legislative and government action in particular must always watch out for those other state actors respecting their decision. With, famously, 'no power of purse or sword' (Hamilton, Federalist No 78 (1788)), a greedy attitude may easily become suicidal. For institutions and for people, that is not a natural call. 


\section{International greed}

In the 21 st century, facing legal pluralism in very tangled networks of nation-states, there is also critique of judicial review that addresses greed beyond the nation-state. In one version, critics do not want a national court to engage in international matters. Such critics oppose judicial review of foreign policy, like government decisions to build walls or deploy the military. Clearly, this can easily be mixed with nationalist populism, fueled by xenophobic racism, and more or less colonial. Then, it eventually results in a rejection of court rulings in matters of vital importance to all those affected by war and those forced to leave their homes, those 'others'.

In another version, critics of judicial review may not want international courts to be greedy actors in domestic affairs. Again, this may inform an aggressive rejection of 'foreign judges'. Such criticism then suggests that international and human rights courts suffer from an utter lack of legitimacy, and lack sufficient knowledge of who 'we really are'. Again, it is my impression that these critics tend not to oppose trade law, as in the World Trade Organization or trade agreements, as long as human rights or social clauses are not binding or are easy to circumvent, while the critique targets rulings that protect human rights or the International Criminal Court's proceedings against war criminals or regional tribunals that adjudicate crimes against humanity, including genocide and gender crimes when rape is used as a means of warfare. Such a rejection of judicial review in fact leaves the military or a government alone, not to be held responsible, and it leaves people behind in pain.

This clearly betrays the 'never again'. Yet, in addition, it ignores globalisation. The radical change in the world's make-up is not limited to online shopping, but is a reality in all spheres of life, including the law. Therefore, not only is there a need for international courts to handle international conflicts short of war, but national courts must also go global. Again, the UK Supreme Court is an influential avant-garde institution, in that it dived head first into application of the European Convention of Human Rights, via the Human Rights Act. And this is not a one-way street. Today, the UK court is an influential voice in making sense of that document, for the UK and way beyond, and in a conversation with many courts that apply the Convention. And while national constitutional courts take regional and international law into account, regional and international judicial bodies build their rulings on our ideas, as with the 'constitutional traditions of the member states' in the EU, a concept introduced by, notably, a court, the European Court of Justice (ECJ) (Rs C-11/70 - Internationale Handelsgesellschaft), and now laid down in Article 6 of the Treaty of the European Union and in Article 52 Section 4 of the EU Charter of Fundamental Rights.

Many courts indeed use international human rights law as a device to interpret even their national constitution. For many years now, the German Federal 
Constitutional Court has practised what I call 'embedded constitutionalism', by interpreting the Basic Law in light of all ratified human rights provisions relevant to the case. This puts the national perspective in conversation with regional and global perspectives, as in many contexts today (Jayawickrama 2017). Certainly, this is not always a smooth ride. In conflicts between the yellow press and privacy rights-reporting on the private life of Caroline of Monaco, say — or in conflicts over prison systems and conditions - where Germany differentiates between regular prison and preventive security detention - Strasbourg and Karlsruhe had to explain to each other what mattered and fought over meaning, but eventually cleared common ground, to agree on the baselines. Most recently, the German FCC decided to apply the constitution in light of the Charter, but also to apply the European Charter itself when law determined by the EU is at issue, yet decided to send a case to Luxemburg when there seemed to be a disjuncture between national and European interpretation of a fundamental right (BVerfG, Decision of 16 Nov 2019 - 1 BvR 16/13 and 1 BvR 267/17 - 'right to be forgotten I and II'). Thus, there is an international conversation going on among the courts, a 'Verbund' (Vosskuhle 2009), that may well support the efforts to retain the 'never again', yet including an update on the current state of worldly affairs. Since globalisation is a reality, this is an indispensable conversation.

Again, this is neither easy nor without challenges. We may indeed need to revisit what Neil Walker calls the 'unitary collective particular', because there is no 18thcentury social contractor any more to inform such constitutionalism today (Walker 2019). Also, Dieter Grimm (2010) describes how the 'constitutive border' of the state as a territory has been eroded. That may call for updates, but it does not mean that national courts or judicial review have to go. In German constitutional jurisprudence, the Court developed a doctrine to protect the core values of the Basic Law as its constitutional identity, or 'Verfassungsidentität'. This is, again, not a greedy invention, but makes sense of the 'eternity clause' in Article 79 Section 3 BL, which does not allow for any constitutional amendment to ever change the core content of that Law. Consequently, as the FCC continuously held (BVerfGE 113, 273; 123, 267; 126, 286; $129,78 ; 134,366 ; 140,317)$, no international agreement or institutional arrangement can do so either. ${ }^{15}$ Similarly, a large part of the Russian Constitution is frozen, which is one reason why the Russian court refused to implement a ruling from the ECHR (Constitutional Court of the Russian Federation Judgement of 14 July 2015,

${ }^{15}$ The Court conceptualised 'identity control' next to 'ultra vires' control as standards of review, as an ultima ratio, to stop the nation-state's participation in international activities - for example, implementation of law, or financial support of international activities - when it violates either the basic national constitution, or oversteps the nationally agreed limits of international power. The doctrine, based on eternity clauses in constitutional law, should not be confused with theoretical concepts (e.g., Jacobsohn 2010). 
No. 21-П/2015). However, whenever this leads down a path of dismissing international rulings on the grounds of national ideology, it is a worrying development (on Hungary, see Fabbrini \& Sajó (2019), Halmai (2018), and Kovacs (2017)). Also, international arrangements may be controlled by the limits of the power granted by a nation-state, and stopped, by courts, if institutions act 'ultra vires'. Most importantly, however, courts need to protect democracy and fundamental human rights, to deliver the promise of 'never again'.

\section{Are courts undemocratic?}

Now, there is another rather influential and highly appealing critique of judicial review that courts are unfit to deal with certain questions, because they are not legitimate actors to make law; they are not elected and are thus undemocratic. To clarify whether this is true, one needs to look at how courts are staffed, what they do, and how they do it (e.g., Landfried 2019).

Again, systems differ and mechanisms of checks and balances need to be assessed in context. Yet all depends on what you think is meant by 'legitimate' and 'elected', and thus 'democratic'. In modern constitutional democracies, most judges are indeed elected, sometimes directly by citizens, more often by members of parliament with a requirement for broad consensus (as in the German a two-thirds majority rule). In federal systems, judges may be elected by state representatives, who are, again, elected by the people or by parliament which is, again, elected. Also, judges are regularly sent to international courts by national governments, hopefully elected. And, in some systems, judges are selected by their peers, at best in refined assessments to produce quality rather than to reproduce bias, and they are then appointed by government, deriving its power, again, from elections. So just as in many other positions of power, an actor's legitimation does not necessarily require a direct popular vote.

The more influential claim that portrays judges as illegitimate is the idea that courts do more than 'simply apply the law'. Along these lines, some oppose judicial review as law-making, which informs complaints about 'exaggerated rights' and 'overreach'. This is also not new, but it is flawed. In the German-speaking world, this is the methodological discussion of courts as 'law machines', a 'Rechtsautomat' to deliver rational decisions. Idealist positivist Hans Kelsen, insisting on the normativity of law, called for a systematic application based on the 'Grundnorm', in an all-encompassing hierarchy of norms (for a nuanced analysis of positivism see Lahusen (2011)), to which English legal philosopher H. L. A. Hart added an ethical dimension. Yet already in the 19th and early 20th centuries, legal sociologists-like Eugen Ehrlich or Rudolf Ihering - protested: There is more to judging than being an automat, be it, for Ehrlich, 'lived law', or, for Jhering, 'interests' that inspire, as he stated in 1872, a 'Kampf ums 
Recht', a 'fight for the law', or for the feminist movement at the time that demanded an end to the neutral civil law of contract and torts, which in fact only covered patriarchal inequality and exploitation (Gerhard 1990). For the common law, Lord Bingham (2006) explained beautifully, not least in his Maccabaean Lecture in 2005, that judging is more than applying the law mechanically, but it is making the law in deciding hard cases. And it is somewhat surprising that this must be said, because for the longest time, common law was known to be the site of judge-made law. Or do the critics in fact oppose particular rulings and not that grand tradition?

Adding to the realistic understanding of judging as always also law-making, Lady Hale added in her Maccabaean Lecture in 2007 that since 'an important function of the law in a democracy is the protection of minorities and disadvantaged groups or individuals', 'judges should be able to contribute from a range of different experiences and perspectives, including a minority view' (Hale 2008). The point is thus not that courts apply the law to formerly unknown circumstances, and thus gradually develop the law as well. The point is how this is done, exactly. For courts to be legitimate decision-makers, we need to make sure that all defensible positions count, and that they are designed to reach a consensus acceptable to all. Thus, diversity is needed. And the point is not biology, but perspective (Hunter 2015, Kenney 2012, Rackley 2012). Beyond an unrealistic rejection of judicial review, a realistic assessment calls on us to do better.

Then, there is the criticism of judicial review as 'constitutionalisation'. In constitutional systems in which courts are mandated by law to strike down legislation, as well as having regard to human rights and international law, this is of utmost importance. Again, it appeals to a long-standing intuition. And recently, Lord Sumption, in his BBC Reith Lecture in 2019, praised politics and warned of 'depolitication' (see also comments by Hale (2019) and Loughlin (2019)). Here, the basic concern is that there is too little room for politics if too many options of political choice are taken away by court rulings. Where power is bound by law, the challenge is, more precisely, the 'judicialization of politics' (Shapiro \& Stone Sweet 2002), in that courts limit what politics can do.

Attacks along these lines are mostly superficial and overly generalised: that is, populist. But as critique, the warning against judicialisation is an important and constant reminder of what courts have to do, and what they should abstain from doing. However, it is a reminder, not a rejection. And it deserves a response.

In fact, courts are not suicidal, nor greedy. Since they have 'no purse or sword' but only the power of words at hand, they depend upon respect. This already informs a natural call for restraint. Also, look at the numbers: How often do courts in fact strike down a law or curtail governmental action? You will read of it, or hear of it, because the bulk of court decisions are not scandalous enough, and thus are not reported. 
In Germany, this results in 98 per cent of FCC rulings remaining unknown, and unheard of. Regarding quantity, there is thus no greed.

Regarding quality, it is important to take a close look at court practice as well. If courts rule and strike down an act of government or legislation as 'active' courts, do they really limit politics? Indeed, one must read the rulings. Media headlines that depend on scandalising to get attention will report a 'blow' or a 'hit' or a 'defeat', but constitutional and human rights courts in fact do not simply say 'no' to politics. Instead, courts draw red lines where politics go too far. And very often, courts open the door for politics, in that they uphold rules of democracy, both in and outside parliament, and issue remedies that call on politics to revisit the question, rather than fully answer it themselves. As such, remedies are of utmost importance and devising them a rather complicated craft. Often, courts require a legislature to legislate again, with more or less time to reconsider; sometimes, courts proceduralise in that they require a political heuristics, to take all needs into account. But, most importantly, judicial review defines the outer limits of politics, and not its future content. Therefore, the warning that courts should not go too far is important, but their function is to intervene in politics.

\section{NEVER AGAIN-FOR WHOM?}

Thus, there are strong arguments, based on the reality of court practice, to defend judicial review against its critics. But I wonder whether I have got all of you on board. Remember that populists are very good at activating fuzzy resentment, and that they actively seek to enlist lawyers, academics, and people interested in politics, to turn skepticism into a rejection of judicial review. Remember how 'we the people' turned from a call for fundamental human rights and democracy into a rallying cry of hatred. Therefore, we need more than conceptual arguments, advanced theories of adjudication, and sociolegal knowledge of what courts really do to defeat the worries. In addition, and maybe even more foundational, we need to know why we should care and for whom. The key argument, then, to defend judicial review is to go back to its roots: that 'never again' shall not be an empty promise. We committed ourselves to care for people in pain, the other.

This focus on people may not be the - or not be enough of a - focus of mainstream work on law and jurisprudence. But it is the historical agreement and our responsibility. Also, and not coincidentally, it is the focus of critical legal studies, as in feminist intersectional legal theory, in anti-racist, post-colonial work and in more anti-hierarchical work on constitutionalism. We care for people. 
Specifically, a defence of judicial review is based on a focus on people in pain. They are why each and every one should care. It is people who do not automatically belong to the 'we', those not privileged, those excluded from the 'normal', the other. So if you care, you have good reasons to defend judicial review. And a final scan of what courts do for democracy, for dignity, liberty, and equality, exemplifies in detail why.

\section{Representative democracy}

First, judicial review has a key function for democracy (see also Bryde 2006, Daly 2017). Who cares for all people to have a voice, as the basic condition of a democratic polity?

Note that some the harshest rejections of judicial review react to court rulings that directly interfere with the democratic process itself. Such decisions are among the most sensitive, because they directly confront those in political power. Here, a court is also obviously both a court and a political intervenor. Keep in mind that courts do not pick and choose to act, but need to be asked, in a predefined procedure, to respond, based not on interest or ideology, but on the law. And, without courts, who would keep the political process alive?

Take election laws. There, people in parliament and government organise who will be there next time. One might assume that they are inclined to privilege those who are in. Therefore, election laws always risk favouring some interest over another, those who are in over those who are out, incumbents over newcomers. This is why a quorum to keep small parties out -3 per cent in European elections, 5 per cent in German elections - needs to be justified. This is why money in politics should be checked, as in party financing and campaign spending, as should access to public fora like broadcasting, and city halls and university campuses. And this is why the mechanisms of election laws need to be carefully scrutinised to allow for others to have a voice, and eventually even to take over. When democratic participation is organised by law, it is naive to say that the people can take care of this. When the legislature changes the rules of the game, the people may not have enough or even anything to say. Therefore, an independent institution is needed to check on the basics of democracy. And courts have been designed to be just that.

Be sure, today's populists get that. Note that autocrats attack courts with the power of judicial review early, and they do so for a reason. In most democracies, judicial review is the only efficient means to stop those once elected from closing the shop, in an illiberal and autocratic regime that dresses as democracy (on Hungary, see Uitz (2015)). It is part of a defensive constitutionalism. Based on an understanding to 'never again' have parties, state-funded when they participate in elections, 
destroy democracy, the German FCC, as early as 1952 and 1956, prohibited both the neofascist Socialist Reich Party (BVerfGE 2,1) and the Communist Party (BVerfGE $5,85)$. The rulings still make interesting reading. In 1958, somewhat more controversially, the Court protected a courageous civil servant calling for a boycott of a movie by Veit Harlan, the director of an anti-Semitic, highly manipulative propaganda piece, Jud Süß. This decision featured free speech, with a reference, in English, to US Justice Cardozo (BVerfGE 7, $198<208>$ ). And all of these can be read, as can many rulings by courts in young democracies, as 'never again'.

To safeguard a democracy that deserves the name, courts do much more. Take the internal rules of parliament. Again, there tends to be an allergic reaction by politicians when courts interfere. Yet who is there to make sure a small opposition party, or an individual MP with the courage to oppose the mainstream, has a say (e.g., BVerfGE $80,188)$ ? How do we make sure the opposition in parliament and every individual MP retains the right to speak, to ask questions, and to get information?

Some courts do. When the German FCC did it, those in power did not like it. This is the moment in which courts are a 'countermajoritarian force', as Hamilton said in the Federalist Papers No. 78 (1788), and revitalised by Bickel in 1962 (Bickel 1962, Ackerman 1983/84). When John Bercow, as Speaker of the House of Commons, proposed a Royal Commission or Speaker's Conference to explore the 'desirability of a written constitution for the UK' in order to resist 'executive malpractices' (The Guardian 2019), is that what he had in mind? In the 2009 Maccabaean Lecture, John Baker said that there is a necessity for making media and the public 'more aware of what is happening and in alerting them to the dangers of allowing the Governmentany Government - to tinker on its own initiative with the controls on its own conduct' (Baker 2010). Who should control this conduct? Whenever there is a need for independent review, courts are designed to do it.

All of this becomes even more complicated when things go post-national, be it regionally European or global. Today, and way beyond the EU, nation-states are deeply intertwined, entangled, interdependent, and also in the law. But when nations go international, what does democracy look like? A citizen's vote and voice have less impact. In the old days, 'foreign affairs' were left to the diplomacy of government. But, again, governments may go too far and do too little; they may wage war, or sell the country, or do other wrong. In a world more connected than ever, trust in purely executive diplomacy may be as outdated as an idea of a national government making one country great again on its own. So, if democracy still means having a say in meaningful decisions, it needs to be extended to international relations as well.

And you know what I mean. Take military operations. In 1644, Cromwell established the New Model Army, and in 1689, the Bill of Rights - an anniversary!required parliament to participate in military matters. The Germans followed suit, 
much later. In 1848, parliament got the right to fix the army's budget, which led to the Prussian constitutional conflict in 1862. But the FCC established in our globalised age, and successively extended and refined, a necessity to ask parliament before sending troops abroad: This was not a greedy court messing with things they didn't have a clue about. Rather, it argued, the 'potential of power' of the military shall not be left to the executive alone, but must be integrated into a constitutional order based on the democratic rule of law (BVerfGE 89, 38 and 90, $286<381>-1994$ : Out of area Somalia; 104, 151 - 2001: NATO; 118, 244 - Afghanistan; 121, $135<$ Rn. 57> - 2008: Turkey).

One key argument to defend judicial review is, thus, safeguarding democracy itself. This is also evident in rulings on the rights of critics to rally and speak their mind, as in decisions that defend the arts against censorship. It is not the majority or the elites that invite those protestors in, but it is courts that make sure outsiders have a voice and get the opportunity to shout out loud.

As to their democratic function, there is another aspect of courts. In fact, court hearings often restage democratic discourse, much needed in particular when politics do not live up to the discursive call.

Have you watched the colloquium on the UK political system in the prorogation case? ${ }^{16}$ It was a deliberation of a public matter, a democratic exercise. It happened in a courtroom, and was thus very organised, with many perspectives present, people prepared and present to listen, no one yelling, or reading the paper, or moaning aloud, if I remember correctly, and no one was asleep.

Again procedure and practice of courts differ. In some legal systems, supreme courts do not hear much from many, but read a lot, much of it published online. Elsewhere, courts organise grand hearings, some rather colloquial in style, others more formal. In Germany, the FCC does not allow cameras in a hearing, and stages few but extensive hearings, whereas in Brazil, hearings and deliberations are televised. But beyond differences in detail, institutional design allows most courts with the power of judicial review to restage an exposure of the issues that democrats may only dream of.

Those who sat through the several days of hearings in Karlsruhe on whether to prohibit the new Nazi party felt that there was a particular quality to this. In a full day of hearing statements and some music to decide whether sampling in hip hop is protected as art or a violation of immaterial property rights, in times of endless reproduction and copying, way past what Walter Benjamin ever imagined, people who listened and watched saw many dimensions of the problem systematically exposed in

${ }^{16}$ The judgement, summary, and video on demand coverage of the prorogation-related cases are available from the website of The Supreme Court: https://www.supremecourt.uk/prorogation/index.html 
front of eight Justices with very different understandings of the issue. It was a discourse parliaments rarely see.

This is particularly relevant in cases which are deeply controversial. Regarding assisted suicide, the highest courts hear from those who desperately seek, those who ideologically defend, and those who oppose assisted suicide, and the rules of procedure orchestrate an exposure of facts and perspectives and legal arguments rarely found anywhere else. Again, some argue that such moral issues are not for the court, and, certainly, they are never for a court alone. But when it comes to a decision about whether someone is allowed to die, or her husband subject to prison because he helped her, such deeply divisive conflicts may profit tremendously from a well-informed and orchestrated debate, bound by basic standards, obliged to give reasons, and to make a decision.

In the German court, visiting politicians and journalists, lobbyists and citizens are often fascinated by such discussions, which they had not seen before. It seems that supreme and constitutional and international and human rights courts restage a discourse from which decisions derive legitimacy. The weaker the political system, the more courts are not only counter-majoritarian safety belts, but have a representative role. Therefore, judicial review is not undemocratic, but is sometimes a forum to restage some democracy.

\section{Dignity}

Secondly, judicial review is an institutional mechanism to make sure the great promise of human dignity as equal respect is not an empty one. This is particularly difficult if the promise is as grand as human dignity. However, courts around the world make this work as a reality.

Examples are many. One may start with what most people hopefully agree on, that dignity informs the prohibition of torture. Today, courts are called upon to go international, and stop sending people off to any place where torture is practised. The German Court stated that one cannot lend a hand to those who torture (BVerfGE 140,317 ), and thus also cannot share information, as in secret service data, with those who torture (BVerfGE 141, 220). Is this going too far? I would defend it as 'never again'.

And there are more questions. Is there a right to a dignified life, in London, or Berlin, or wherever you live? The FCC, when asked to protect the poor, reminded politics and society of the great consensus after 1945: 'never again'. It held that no one should be left in precarious conditions, and everyone deserves, qua being human, enough support to live a dignified life. The Court has said, in several decisions up to 
now (BVerfGE 125, 175; 132, 134; 137, 34), that there is a fundamental human right to an existential minimum. Is this going too far and does the court encroach on politics? Do courts, when they apply a grand promise like dignity to budgetary decisions in the welfare state, overly 'constitutionalise' the issue, and 'depoliticise' it?

Again, one needs to look at what courts do in detail, and specifically discuss remedies. The German decisions on the existential minimum, including the recent ruling on sanctions in a workfare system, made sure that it is up to politics to decide how much exactly shall be given to those in need, what exactly to ask of them to take care of themselves, if it is not unbearable, and how to implement such a demand by way of sanctions. Over and over again, the ruling states that, if the legislature decides, the Constitution does not block its decision but sets outer limits on how far legislation can go (BVerfG, Judgment of the First Senate of 5 Nov 2019 - 1 BvL 7/16).

Finally politicians were, and often are, rather happy to have a court decide this basic controversy. Indeed, such a hot potato is often passed to courts to save politics from burning its hands. But courts are not stupid either; we get that. So our rulings are also attempts not to fully answer political questions, and not to attract all the blame. Rather, by way of nuanced remedies, courts allow and often require politics to act. Therefore, judicial review is not the end of politics, but forces politics to leave no one behind.

\section{Liberty}

Thirdly, liberty. Generally, rulings on liberty inform less allergic reactions to judicial review, since it is the accepted classic rule of courts to protect one's basic freedom. Yet when there are new threats to liberty, things tend to change, and autocrats may prefer to decide themselves who enjoys liberty.

Now in the 21 st century, many courts are called upon to decide issues of data security and surveillance. Again, we see attacks on what is called 'excessive' intervention by, for example, an 'overly detailed' use of proportionality, and 'free' balancing of all rights and interests relevant in the context. Again, one key question should be what is at stake and who will suffer when courts stay out if it?

Regarding the right to what we call 'informational self-determination', slightly different from a right to 'privacy', the German Court became a strong voice in the discussion. In a nation that lived through fascism and half a nation that lived with the Stasi secret police, there is a strong historical inclination to really make sure 'never again'. In constitutional law, liberty is read in conjunction with dignity and taken as a right of habeas data, a right to decide for yourself what you want others to know about you and what to do with such information. It started with a decision that did 
not stop politics from running a census (BVerfGE 65, 1), but limited the type and use of data to be taken. Again, this did not 'depoliticise' the issue, but framed the space for politics. Since then, there has been a long line of decisions that did not ignore the need to prevent terrorism and use surveillance to fight crime, but limited the means in light of the rights affected, and thus demanded proportionality, summarised in the ruling on the Federal Police 'BKA' (BVerfGE 141, 220). Right now, we are in the middle of discussing whether the secret service may listen to your phone calls, read your messages and emails, and follow your online searches when you are in another country, and to share this with the UK, the US, and many more countries, to prevent terrorist attacks. It is for all of us to discuss this. But courts are designed to orchestrate that much is said, to listen to it from diverse perspectives, and to make a decision that is based on principles and is well reasoned. If courts stay out of it - would we impress George Orwell? Would you get social points, as in China, and be constantly assessed, with consequences? If such levels of control should not be accepted again, courts have a function.

\section{Equality}

Finally, the third promise of the grand consensus of fundamental human rights is equality. Unlike liberty, there are many allergic reactions to judicial review based on the assumption that there are really no standards, and that this is all social, and not for the courts to decide who to compare to whom. Yet again, there are good arguments and many examples to defend judicial review. And the key question is: What is equality really about? And who suffers if the promise is not kept?

In a formalistic interpretation, equality is about sameness and difference, and, indeed, the legislature may define what matters in this. Yet, today, equality is the right to diversity based on equal respect, as substantive equality, a right to non-discrimination (see Baer (1998) and Baer \&Markard (2019), for comparative material see Dorsen et al. (2016)).

This is very much in line with history. In many societies, equality was a key driver of movements that led to the grand statements of fundamental rights, be it equal political standing with the nobility and the wealthy, or equal respect for all those considered the other, from women's right to vote to the end of colonialism to racism today, from tearing down patriarchy (for example, by ending the rule of male veto in family matters (BVerfGE 10,59-1959)) to deconstructing heteronormativity and rejecting sexism in 2019, from fighting euthanasia to an end to removing people out of sight and instead lowering the barriers that make them disabled. It was global movements against colonialism and racism and sexism and homo- and transphobia and ableism etc. that created the Universal Declaration of Human Rights, the 
European and other regional conventions, the specific UN treaties, national and local law against discrimination, and informed the 'never again'.

When courts make sure these are not just empty promises, are they going too far? When the European Court of Human Rights protects transsexuals in living their lives, and also in the UK, as do many courts around the world (Goodwin \& I v United Kingdom [2002] 2 FCR 577, for comparative material see Dorsen et al. (2016)) exactly because it is a small pathologised and persecuted minority in most places, is this overreach? When the German court recently decided that registration laws must respect that not all human beings are clearly men or women, is this too much?

Imagine

So imagine a world without judicial review. Imagine if autocrats succeed in enlisting the critics of the global rise of 'new constitutionalism', and denounce courts as illegitimate, unelected, and thus non-democratic greedy juristocrats, with an expansive interpretation of the law, messing with diplomacy and international matters, whereas they should defend and only care for the nation-state, as defined by those in power.

Would parliament make rules that allow newcomers in, and oppositional voices to be heard - and what if they did not?

Who would protect critical journalism, as well as teaching and research-in a world without an implemented guarantee of freedom of speech, the press, and broadcasting? Imagine a world without a Speaker's Corner in Hyde Park, or anywhere else. If you have a voice and do not need a soapbox to stand on, you may not care. You may then also not need a court. But, otherwise, you do.

How would you make sure that people are not sent off to be tortured, or suffer degrading conditions in poverty? Without judicial review, which institution would remind politicians, and eventually enforce the promise, that there is a commitment to dignity for all? Who would ensure liberty, in times in which governments and global companies have a keen interest in our data? What is the device for protection against discrimination, be it racism or sexism, ableism or more? If you belong to a normality, and if others see you as that as well, you might not need a court. But are you sure that you will be as privileged tomorrow? Autocrats all over Europe are rediscovering anti-Semitism in scary dimensions and forms. Populists employ a variety of complicated prejudices. You might be next on their list. And if you are not-will you care for others who are? Sometimes, to reject judicial review may in fact be a rather elitist, and then a naïve, position.

Finally, to not rule on a case - that is to consider an issue 'unjusticiable' or a 'political question' - is to deny a fair hearing to those who disagree, and not to offer 
protection to those in pain. I think we agreed that this should never happen again. In philosophical terms, to refuse to decide is to shy away from the Derridean moment of responsibility ${ }^{17}$ In a critical exposure of the violence of the law, Derrida identifies, especially in hard cases, a moment where one must decide: an ethical moment. This is exactly the moment courts are designed to face, as institutions, because their power does not rest on money or sheer force, and cannot not be based ad hoc intuition or impressions and trends or path-dependency. Rather, courts are designed to prepare, by exposure to different perspectives, to listen, organised by procedural requirements of a fair hearing, and to argue, based on law, as in rules and precedent.

The argument is, then, that, if Magna Carta is to be a guarantee for all, and if our post-WWII consensus on fundamental human rights is not an empty promise, we need judicial review. The whole point of constitutionalism is that politicians, even in the form of large elected majorities, can do wrong, and that there should be courts to stop them, bound by law. Do not allow populism to fool you. Judicial review is an important instrument to deliver the promise of 'never again'. And 2019 is a year in which to revitalise that promise.

Acknowledgments: Special thanks go to the team I work with at the Court, for ideas and support, namely Thomas Payrhuber, and for patient editing, to Jan Schubert.

\section{REFERENCES}

Ackerman, B. (1983/84), 'Discovering the Constitution', The Yale Law Journal, 93: 1013-72. https://doi.org/10.2307/796204

Albright, M. (2018), Fascism: A Warning (London, HarperCollins).

Arendt, H. (1963), Eichmann in Jerusalem: A Report on the Banality of Evil (New York, Viking Press).

Baer, H. (2011), Judges Under Fire: Human Rights, Independent Judiciary, and the Rule of Law (Chicago, IL, American Bar Association).

Baer, S. (1998), 'Equality: The Jurisprudence of the German Constitutional Court', Columbia Journal of European Law, 5: 249-80.

Baer, S. (2019a), 'Democracy in Peril: A Call for Amici and Amicae Curiae and Critical Lawyering', Transnational Legal Theory, 10: 140-62. https://doi.org/10.1080/20414005.2019.1635810

Baer, S. (2019b), 'Grundrechte unter Druck', in M. Ruffert (ed.) Europa-Visionen (Baden-Baden, Nomos), 169-92. https://doi.org/10.5771/9783845295473-169

Baer, S. \& Markard, N. (2018), Art. 3 Abs. 2, Art. 3 Abs. 3, in: v. Mangoldt, Klein, Starck, Kommentar zum Grundgesetz: $G G, 7$. Aufl.

Baer, U. (2019), What Snowflakes Get Right: Free Speech and Truth on Campus (New York, Oxford University Press). https://doi.org/10.1093/oso/9780190054199.001.0001

${ }^{17}$ French philosopher Jaques Derrida (1989-90) discussed a text by Walter Benjamin on police powers in early-20th-century Germany (Benjamin 1996 [1921]), to focus on an ethical moment in deciding cases based on law (see with comments in Cornell et al. 2016). 
Baker, J. (2010), 'Our Unwritten Constitution', Proceedings of the British Academy, 167: 91-117. https://doi.org/10.5871/bacad/9780197264775.003.0004

Benda, E. (1972), Der Rechtsstaat in der Krise: Autorität und Glaubwürdigkeit der demokratischen Ordnung (Stuttgart, Seewald).

Benjamin, W. (1996 [1921]), Critique of Violence, Selected Writings; Volume 1; 1913-1926 (Cambridge, MA, The Belknap Press of Harvard University Press).

Bickel, A. (1962), The Least Dangerous Branch (Indianapolis, IN, Bobbs-Merrill).

Bingham, Lord (Bingham) of Cornhill (2006), 'The Judges: Active or Passive?', Proceedings of the British Academy, 139: 55-72. https://doi.org/10.5871/bacad/9780197263945.003.0003

Bryde, B. O. (2006), 'Der Beitrag des Bundesverfassungsgerichts zur Demokratisierung der Bundesrepublik', in C. Mollers \& C. van Ooyen (eds) Das Bundesverfassungsgericht im politischen System (Wiesbaden, Verlag für Sozialwissenschaften), 321-32. https://doi.org/10.1007/978-3-531-90289-0_24

Bude, H. (2019), 'Pegida, die Gesellschaft der Angst und der Protestbegriff des Volkes', in R. Haubl \& H. J. Wirth (eds) Grenzerfahrungen: Migration, Flucht, Vertreibung und die deutschen Verhältnisse (Baden-Baden, Nomos), 57-70. https://doi.org/10.30820/9783837974867-57

Buergenthal, T. (2004), 'New Upload-Remembering the Early Years of the Inter-American Court of Human Rights', New York University Journal of International Law and Politics, 37, 259-80.

Bugaric, B. (2019), 'Central Europe's Descent Into Autocracy: A Constitutional Analysis of Authoritarian Populism', International Journal of Constitutional Law, 17(2): 597-616. https://doi.org/10.1093/icon/moz032

Collings, Justin (2015), Democracy's Guardians: A History of the German Federal Constitutional Court, 1951-2001 (Oxford, Oxford University Press).

https://doi.org/10.1093/acprof:oso/9780198753377.001.0001

Contesse, J. (2017), 'The Final Word? Constitutional Dialogue and the Inter-American Court Of Human Rights', International Journal of Constitutional Law, 15(2): 414-35. https://doi.org/10.1093/icon/mox034

Cornell, D., Rosenfeld, M. \& Carlson, D. G. (2016), Deconstruction and the Possibility of Justice reprint (London, Routledge). https://doi.org/10.4324/9781315539744

Corrales, J. (2015), 'The Authoritarian Resurgence: Autocratic Legalism in Venezuela', Journal of Democracy, 26(2): 37-51. https://doi.org/10.1353/jod.2015.0031

Daly, T. G. (2017), The Alchemists. Questioning our Faith in Courts as Democracy-builders (Cambridge, Cambridge University Press). https://doi.org/10.1017/9781108283731

Daly, T. G. \& Wiebusch, M. (2018), 'The African Court on Human and Peoples' Rights: Mapping Resistance Against a Young Court', International Journal of Law in Context, 14(2): 294-313. https://doi.org/10.1017/S1744552318000083

Derrida, J. (1989-90), 'Force of Law: The "Mythical Foundation of Authority" ', Cardozo Law Review, 11: $919-1045$.

Dietze, G, (2017), Sexualpolitik: Verflechtungen von Race und Gender (Frankfurt, Campus-Verlag).

Dietze, G. (2018), 'Rechtspopulismus und Geschlecht: Paradox und Leitmotiv', Femina Politica, 27(1): 34-46. https://doi.org/10.3224/feminapolitica.v27i1.04

Di Fabio, U. (2015), 'Migrationskrise als föderales Verfassungsproblem', ZSE / Journal for Comparative Government and European Policy, 13(4): 517-41. https://doi.org/10.5771/1610-7780-2015-4-517

Dixon, R. \& Landau, D. (2019), '1989-2019: From Democratic to Abusive Constitutional Borrowing', International Journal of Constitutional Law, 17(2): 489-96. https://doi.org/10.1093/icon/moz038

Dorsen, N., Rosenfeld, M., Sajo, A., Baer, S. \& Mancini, S. (2016), Comparative Constitutionalism 3rd edn (Saint Paul, MN, West Academic Publishing). 
Dreier, H. \& Waldhoff, C. (eds) (2018), Das Wagnis der Demokratie. Eine Anatomie der Weimarer Reichsverfassung (Munich, C. H. Beck). https://doi.org/10.17104/9783406726774

Fabbrini, F. \& Sajó, A. (2019), 'The Dangers of Constitutional Identity', European Law Journal, 25(4): 457-73. https://doi.org/10.1111/eulj.12332

Ferber, M. A. \& Nelson, J. A. (eds) (2009), Beyond Economic Man: Feminist Theory and Economics (Chicago, IL, University of Chicago Press).

Gerhard, U. (1990), Gleichheit ohne Angleichung (Frankfurt, C. H. Beck).

Ginsburg, T. \& Huq, A. Z. (eds) (2016), Assessing Constitutional Performance (Cambridge, Cambridge University Press). https://doi.org/10.1017/CBO9781316651018

Grimm, D. (2010), 'The Achievement of Constitutionalism and Its Prospects in a Changed World', in M. Loughlin \& P. Dobner (eds) The Twilight of Constitutionalism? (Oxford, Oxford University Press), 3-22. https://doi.org/10.1093/acprof:oso/9780199585007.003.0001

Grimm, D. (2016), Constitutionalism: Past, Present, and Future (Oxford, Oxford University Press). https://doi.org/10.1093/acprof:oso/9780198766124.001.0001

Gusy, C. (1997), Die Weimarer Reichsverfassung (Tübingen, Mohr Siebeck).

Hale, B. (2008), 'A Minority Opinion?', Proceedings of the British Academy, 154: 319-36.

Hale, B. (2019), Law and Politics. A Reply to Reith, Dame Francis Patterson Memorial Lecture. https://www.supremecourt.uk/docs/speech-191008.pdf

Halmai, G. (2018), 'Abuse of Constitutional Identity. The Hungarian Constitutional Court on Interpretation of Article E)(2) of the Fundamental Law', Review of Central and East European Law, 43(1): 23-42. https://doi.org/10.1163/15730352-04301002

Hamilton, Alexander (1788), 'The Judiciary Department', Federalist No. 78. https://www.congress.gov/ resources/display/content/The+Federalist+Papers\#TheFederalistPapers-78

Hark, S. \& Villa, P. I. (2017), Unterscheiden und herrschen: ein Essay zu den ambivalenten Verflechtungen von Rassismus, Sexismus und Feminismus in der Gegenwart (Bielefeld, transcript Verlag). https://doi.org/10.14361/9783839436530

Hirschl, R. (2009), Towards Juristocracy: The Origins and Consequences of the New Constitutionalism (Cambridge, MA, Harvard University Press).

Human Rights Act 1998, UK Public General Acts c.42. http://www.legislation.gov.uk/ukpga/1998/42/contents

Hunter, R. (2015), 'More Than Just a Different Face? Judicial Diversity and Decision-making', Current Legal Problems, 68(1): 119-41. https://doi.org/10.1093/clp/cuv001

Jacobsohn, G. J. (2010), Constitutional Identity (Princeton, NJ, Princeton University Press).

Jalloh, C. C., Clarke, K. M. \& Nmehielle, V. O. (eds) (2019), The African Court of Justice and Human and Peoples' Rights in Context: Development and Challenges (Cambridge, Cambridge University Press). https://doi.org/10.1017/9781108525343

Jayawickrama, N. (2017), The Judicial Application of Human Rights Law. National, Regional and International Jurisprudence, 2nd edn (Cambridge, Cambridge University Press). https://doi.org/10.1017/9781139059121

Jörke, D. \& Nachtwey, O. (eds) (2017), Das Volk gegen die (liberale) Demokratie, Leviathan Sonderheft 32 (Baden-Baden, Nomos). https://doi.org/10.5771/9783845287843

Kadelbach, Stefan (ed.) (2018), Verfassungskrisen in der Europäischen Union (Baden-Baden, Nomos). https://doi.org/10.5771/9783845293004

Kenney, S. J. (2012), Gender and Justice: Why Women in the Judiciary Really Matter (London, Routledge). https://doi.org/10.4324/9780203122297

Kommers, D. P. \& Miller, R. A. (2012), The Constitutional Jurisprudence of the Federal Republic of Germany: Revised and Expanded (Durham, NC, Duke University Press). https://doi.org/10.1215/9780822395386 
Koncewicz, T. T. (2019), 'Understanding the Politics of Resentment: Of the Principles, Institutions, Counter-strategies, Normative Change, and the Habits of Heart', Indiana Journal of Global Legal Studies, 26(2): 501-630. https://doi.org/10.2979/indjglolegstu.26.2.0501

Kovacs, K. (2017), 'The Rise of an Ethnocultural Constitutional Identity in the Jurisprudence of the East Central European Courts', German Law Journal, 18(7): 1703-20. https://doi.org/10.1017/S2071832200022501

Krastev, Ivan \& Holmes, Stephen (2019), The Light That Failed: A Reckoning (London, Penguin).

Lacey, N. (2019), 'Populism and the Rule of Law', Annual Review of Law and Social Science, 15: 79-96. https://doi.org/10.1146/annurev-lawsocsci-101518-042919

Lahusen, B. (2011), Rechtspositivismus und Juristische Methode. Betrachtungen aus dem Alltag einer Vernunftehe (Weilerswist-Metternich, Velbrück Wissenschaft).

Lambert, E. (1921), Le Gouvernement des juges et la lutte contre la législation sociale aux États-Unis, l'expérience américaine du contrôle judiciaire de la constitutionnalité des lois (Lyon, Persée).

Lamprecht, R. (2011), Ich gehe bis nach Karlsruhe. Eine Geschichte des Bundesverfassungsgerichts (Munich, Deutsche Verlags-Anstalt).

Landau, D. (2013), 'Abusive Constitutionalism', UC Davis Law Review, 47(1): 189-260.

Landfried, C. (ed.) (2019), Judicial Power. How Constitutional Courts Affect Political Transformation (Cambridge, Cambridge University Press). https://doi.org/10.1017/9781108348669

Lembcke, O. (2007), Hüter der Verfassung. Eine institutionentheoretische Studie zur Autorität des Bundesverfassungsgerichts (Tübingen, Mohr Siebeck).

Loughlin, M. (2019), 'What would John Griffith have made of Jonathan Sumption's Reith Lectures?', The Political Quarterly, 90(4): 785-93. https://doi.org/10.1111/1467-923X.12771

Müller M. \& Precht, J. (eds) (2019), Narrative des Populismus. Erzählmuster- und strukturen populistischer Politik (Basel, VS Verlag für Sozialwissenschaften).

https://doi.org/10.1007/978-3-658-22374-8

Neves, M. (1997), 'Lateinamerikanische Verfassungen: Zwischen Autokratismus und Demokratisierung', Verfassung und Recht in Übersee/Law and Politics in Africa, Asia and Latin America, 30(4): 503-19. https://doi.org/10.5771/0506-7286-1997-4-503

Nussberger, A. (2019), ‘60 Jahre Europäischer Gerichtshof für Menschenrechte', Deutsche Richterzeitung, 4: 114-17.

Oberleitner, G. (ed.) (2018), International Human Rights Institutions, Tribunals, and Courts (Singapore, Springer Singapore). https://doi.org/10.1007/978-981-10-4516-5

Preuß, U. K. (2017), 'Die Krise der Europäischen Union als Ausnahmezustand?', Kritische Justiz, 50(1): 51-67. https://doi.org/10.5771/0023-4834-2017-1-51

Rackley, E. (2012), Women, Judging and the Judiciary: From Difference to Diversity (London, Routledge). https://doi.org/10.4324/9780203098189

Scheppele K. L. (2018), 'Autocratic Legalism', University of Chicago Law Review, 85(2): 545-83.

Schor, M. (2008), 'Mapping Comparative Judicial Review', Washington University Global Studies Law Review, 7: 257-87.

Sen, A. (1999), 'Democracy as a Universal Value', Journal of Democracy, 10: 3-17. https://doi.org/10.1353/jod.1999.0055

Shapiro, M. \& Stone, A. (1994), 'The New Constitutional Politics of Europe', Comparative Political Studies, 26(4): 397-420. https://doi.org/10.1177/0010414094026004001

Shapiro, M. \& Stone Sweet, A. S. (2002), On Law, Politics, and Judicialization (New York, Oxford University Press). https://doi.org/10.1093/0199256489.001.0001

Simpson, B. (2004), 'The Rule of Law in International Affairs', Proceedings of the British Academy, 125: 211-63. https://doi.org/10.5871/bacad/9780197263242.003.0010

Stolleis, M. (ed.) (2011), Herzkammern der Republik. Die Deutschen und das Bundesverfassungsgericht (Munich, C. H. Beck). 
Stone Sweet, A. (2000), Governing With Judges: Constitutional Politics in Europe (Oxford, Oxford University Press). https://doi.org/10.1093/0198297718.003.0007

Sturgess, G. \& Chubb, P. (1988), Judging the World: Law and Politics in the World's Leading Courts (Sydney, Butterworths (Australia)).

Sumption, Jonathan (2019), 'In Praise of Politics', The Reith Lectures 2019, No. 2. https://www.bbc.co.uk/programmes/m0005f05

The Guardian (2019), 'John Bercow: I'll Stop Boris Johnson Breaking the Law on Brexit', 12 September. https://www.theguardian.com/politics/2019/sep/12/bercow-warns-pm-not-to-defy-law-on-nodeal-brexit

Uitz, R. (2015), 'Can You Tell When an Illiberal Democracy Is in the Making? An Appeal to Comparative Constitutional Scholarship from Hungary', International Journal of Constitutional Law, 13(1): 279-300. https://doi.org/10.1093/icon/mov012

Vermeulen, A. (2006), Judging under Uncertainty (Cambridge, MA, Harvard University Press).

Vosskuhle, A. (2009), 'Der europäische Verfassungsgerichtsverbund', TranState Working Papers 106, University of Bremen, Collaborative Research Center 597: Transformations of the State.

Waldron, J. (2006), 'The Core of the Case Against Judicial Review', Yale Law Review, 115: 1364-9. https://doi.org/10.2307/20455656

Walker, N. (2019), 'Populism and Constitutional Tension', International Journal of Constitutional Law, 17(2): 515-35. https://doi.org/10.1093/icon/moz027

Wildt, M. (2017), Volk, Volksgemeinschaft, AfD (Hamburg, Hamburger Edition). https://doi.org/10.3726/JP2017.18

To cite the article: Susanne Baer (2020), 'Who cares? A defence of judicial review', Journal of the British Academy, 8: 75-104. DOI https://doi.org/10.5871/jba/008.075

Journal of the British Academy (ISSN 2052-7217) is published by The British Academy, 10-11 Carlton House Terrace, London, SW1Y 5AH www.thebritishacademy.ac.uk 